Article

\title{
Effects of Biostimulant and Organic Amendment on Soil Properties and Nutrient Status of Lactuca Sativa in a Calcareous Saline-Sodic Soil
}

\author{
Sofia Karapouloutidou ${ }^{1}$ and Dionisios Gasparatos ${ }^{2, *(D)}$ \\ 1 Variety Research Department of Cultivated Plants, Ministry of Rural Development and Food, \\ 57400 Sindos, Greece \\ 2 Laboratory of Soil Science, School of Agriculture, Aristotle University of Thessaloniki, \\ 54124 Thessaloniki, Greece \\ * Correspondence: gasparatos@agro.auth.gr or gasparatos@aua.gr
}

Received: 6 June 2019; Accepted: 22 July 2019; Published: 26 July 2019

\begin{abstract}
Many studies have reported the advantages of alternative agricultural practices using more environmentally-friendly products to ameliorate the negative impacts of salinity and sodicity, but few have examined the effects of these products in saline-sodic soils with high soil organic matter (SOM) content. The objective of this research was to examine the effect of biostimulant (Actiwave) and organic amendment (Corresal Plus) product on soil properties and on the nutrient content of lettuce (Lactuca sativa L.). A pot study with a calcareous saline-sodic soil was conducted using a completely randomized design with six treatments: Two rates of the biostimulant (ActA: $101 \mathrm{ha}^{-1}$ and ActB: $151 \mathrm{ha}^{-1}$ ), three rates of the amendment (CorA: $101 \mathrm{ha}^{-1}$, CorB: $151 \mathrm{ha}^{-1}$ and CorC: $501 \mathrm{ha}^{-1}$ ) and a control treatment. The application of Actiwave reduced soil electrical conductivity (E.C.), soil exchangeable $\mathrm{Na}$ and soluble $\mathrm{Cl}$. It also increased leaf $\mathrm{N}$ and $\mathrm{Zn}$ content. On the other hand, the higher dose of Corresal Plus reduced soil $\mathrm{pH}$ and soil exchangeable $\mathrm{Na}$ and increased soil $\mathrm{NO}_{3}-\mathrm{N}$. Additionally, $\mathrm{Cor} C$ treatment decreased leaf $\mathrm{Cl}$ and increased leaf $\mathrm{N}$ content enhancing lettuce growth.. However, in most cases, the two products did not provoke significant changes indicating that their positive effects were probably masked by the high SOM content and the calcareous nature of the studied soil.
\end{abstract}

Keywords: saline-sodic soil; amendment; biostimulant; lettuce; soil fertility; plant nutrients

\section{Introduction}

Salinity-sodicity is among the most widespread soil degradation processes on Earth [1]. In the Mediterranean region, 25\% of irrigated agricultural land is affected by salinization leading soil degradation [2]. Salt stress adversely affects physical and chemical properties of soil, microbiological processes, and plant growth [3-5]. Furthermore, excessive salts cause two major stresses: Osmotic and ionic $[2,6]$. High salt accumulation lowers osmotic potential between plant cells and soil solution while reducing water movement inside the plant [7-9]. High levels of $\mathrm{Na}$ and $\mathrm{Cl}$ concentrations are toxic to plant cells and inhibit the uptake of other essential nutrient ions by plant roots $[10,11]$. At the same time excess amounts of $\mathrm{Na}$, cause phenomena like slaking, swelling, and dispersion of soil aggregates $[2,5]$.

Lettuce (Lactuca sativa L.) is one of the most widespread vegetables worldwide and its production in Europe in 2013 was three million tons [12]. Lettuce is relatively salt-sensitive cultivation and the threshold of electrical conductivity where yield is reduced to $50 \%$ is $5.1 \mathrm{dS} / \mathrm{m}$ [13]. A lettuce variety, called Romaine is more salt-tolerant than another variety called Iceberg [14]. 
The increasing consumption of vegetables is in correspondence with the significant food demands due to the rising human population and the decreasing arable land due to soil degradation. So, the challenge for agriculture is to function in a sustainable way diminishing the over-application of fertilizers and agrochemicals. Integrated nutrient management is a sustainable method which uses all nutrients and man-made sources in a judicious and environmentally friendly manner but without reducing crop's productivity [15].

The application of soil amendments is one of the various agricultural practices that can be used in integrated nutrient management approach [15]. These are substances that can ameliorate soil physical, chemical, and biological properties, promote plant nutrition, and can mitigate the adverse impacts of soil salinity and sodicity. Organic amendments restore soil chemical properties because their application to soil is likely to increase the soil organic matter, cation exchange capacity, chelation and nutrient availability [16,17].

Biostimulants are natural and environmentally friendly substances with positive effects on plant growth enhancing plant metabolism and physiology when applied in small doses. Biostimulants help plants tolerate biotic and abiotic stress and increase their nutrient use efficiency. The most common biostimulants' categories are humic substances, seaweed extracts, amino acid-containing products, and plant growth-promoting microorganisms $[18,19]$. In most cases, biostimulant's effect is based on the synergistic action of all categories, though it is difficult to determine their mechanisms of action [20].

Considering that the continuous increase of salinization on a global scale makes saline-sodic soils the most important category of degraded soils with severe effects on agriculture production, there is an urgent need to minimize further land degradation and restore the fertility of degraded soils. The aim of this work was to evaluate the potential effects of two commercial products, the biostimulant Actiwave, and the organic amendment Corresal Plus, on soil chemical properties and nutrient availability in a calcareous saline-sodic soil. Moreover, we tested the efficacy of these two products on the nutrition of lettuce plants cultivated in this degraded soil. Within this framework, we hypothesized that the biostimulant and organic amendment application could enhance nutrient availability helping lettuce overcome abiotic stress conditions and grow normally.

\section{Materials and Methods}

\subsection{Experimental Design-Plant Material}

The study was conducted at the Laboratory of Soil Science of Aristotle University of Thessaloniki, where lettuce plants (Lactuca sativa var. Romaine, Parris Island Cos) were grown in pots containing saline-sodic soil taken from the farm of the Aristotle University of Thessaloniki $\left(40^{\circ} 32^{\prime} 16 \mathrm{~N}, 22^{\circ} 59^{\prime} 27 \mathrm{E}\right.$, $5 \mathrm{~m}$ (a.s.1.) (Table 1). A mass of $250 \mathrm{~kg}$ of soil was collected over an area of $30 \mathrm{~m}^{2}$ and a depth between 5 and $20 \mathrm{~cm}$. Lettuce plants with two weeks of growth were transplanted into plastic pots filled each with $2 \mathrm{~kg}$ of saline-sodic soil and were grown under controlled conditions (temperature 19-21 ${ }^{\circ} \mathrm{C}$, air moisture $60-70 \%$ and 16 hours of light period with fluorescent lamp Sylvania Grolux). The 54 pots ( 9 replicates $\times 6$ treatments) were each irrigated with $100 \mathrm{ml}$ tap water (Electrical Conductivity $450 \mu \mathrm{S} \mathrm{cm}{ }^{-1}$ ) per week. The experiment was arranged in a completely randomized design.

Two commercial products were used in this study, one biostimulant (Actiwave) and one organic amendment (Corresal Plus). Actiwave is a seaweed extract product derived from Ascophylum nodosum and its three major components are kahydrin, alginic acid, and betaine [21]. Corresal Plus is an organochemical complex used for the reclamation of problem (saline, sodic) soils. The main characteristics of the two products are shown in Table 2.

The treatments were: 1) Control: No product applied, 2) ActA: $101 \mathrm{ha}^{-1}$, 3) ActB: $151 \mathrm{ha}^{-1} 4$ ) CorA: $101 \mathrm{ha}^{-1}$, 5) CorB: $151 \mathrm{ha}^{-1}$, 6) CorC: $501 \mathrm{ha}^{-1}$ following to manufacturers' recommendations. 
Table 1. Selected characteristics of the soil used in the experiment.

\begin{tabular}{|c|c|}
\hline Soil characteristics & \\
\hline Sand $(\%)$ & 25.5 \\
\hline Silt (\%) & 27.6 \\
\hline Clay $(\%)$ & 46.9 \\
\hline Texture & Clay \\
\hline Clay mineralogy * & Montmorillonite, vermiculite, mica \\
\hline pH & 8.15 \\
\hline $\mathrm{CaCO}_{3}(\%)$ & 11.8 \\
\hline Electrical conductivity $\left(\mathrm{mS} \mathrm{cm}^{-1}\right)$ & 13.5 \\
\hline Organic Matter (\%) & 5.85 \\
\hline Cation exchange capacity (meq $100 \mathrm{~g}^{-1}$ ) & 27.8 \\
\hline Exchangeable Sodium Percentage (\%) & 24.4 \\
\hline Available P (mg kg $\left.{ }^{-1}\right)$ & 131.3 \\
\hline Exchangeable $\mathrm{K}$ (meq $100 \mathrm{~g}^{-1}$ ) & 6.10 \\
\hline Exchangeable $\mathrm{Na}\left(\mathrm{meq} 100 \mathrm{~g}^{-1}\right.$ ) & 6.79 \\
\hline Available Fe (mg kg $\left.{ }^{-1}\right)$ & 74.1 \\
\hline Available Mn (mg kg $\left.{ }^{-1}\right)$ & 9.85 \\
\hline Available Zn (mg kg $\left.{ }^{-1}\right)$ & 8.66 \\
\hline
\end{tabular}

Table 2. Composition declared on the labels of the organic amendment (Corresal Plus) and the biostimulant (Actiwave) according to manufacturers (Agrifert S.A. and Valagro Hellas S.A., respectively).

\begin{tabular}{|c|c|c|c|c|c|c|c|}
\hline Product & $\begin{array}{c}\text { Organic } \\
\text { Carbon } \\
(\%)\end{array}$ & $\begin{array}{c}\text { Organic } \\
\text { Acids } \\
(\%)\end{array}$ & $\begin{array}{l}\text { Organic } \\
\text { N (\%) }\end{array}$ & $\begin{array}{c}\text { Total N } \\
(\%)\end{array}$ & $\begin{array}{c}\text { N ureic } \\
(\%)\end{array}$ & $\begin{array}{c}\mathrm{K}_{2} \mathrm{O} \\
(\%)\end{array}$ & $\begin{array}{l}\mathrm{CaO} \\
(\%)\end{array}$ \\
\hline Corresal Plus & 9.25 & 17.6 & 5.8 & 5.8 & - & - & 12.5 \\
\hline \multirow[t]{2}{*}{ Actiwave } & 12.0 & - & 1.0 & 3.0 & 2.0 & 7.0 & - \\
\hline & $\begin{array}{l}\text { Chelate } \\
\text { Ca }(\%)\end{array}$ & $\begin{array}{c}\text { Total Fe } \\
(\%)\end{array}$ & Chelate $\mathrm{Fe}^{1}(\%)$ & $\begin{array}{l}\text { Total Zn } \\
\text { (\%) }\end{array}$ & $\begin{array}{c}\text { Chelate } \mathrm{Zn}{ }^{2} \\
(\%)\end{array}$ & $\mathrm{pH}$ & \\
\hline Corresal Plus & 9.0 & - & - & - & - & $4.0-5.0$ & - \\
\hline Actiwave & - & 0.5 & 0.5 & 0.08 & 0.08 & 6.4 & - \\
\hline
\end{tabular}

${ }^{1}$ Fe-EDDHSA, ${ }^{2}$ Zn-EDTA.

\subsection{Sampling and Analyses}

The lettuce was harvested after a 75-day growing period. The number of leaves and the biomass of plants were calculated. Subsequently, plant tissues were dried at $70^{\circ} \mathrm{C}$ for three days and grounded into powder. The total $\mathrm{N}(\%)$ of the plant tissues was determined using Kjeldahl digestion [23]. Dried plant tissues were ashed in a furnace at $500{ }^{\circ} \mathrm{C}$ for four hours. The ash was extracted with nitric acid $\mathrm{HNO}_{3} 65 \%$. $\mathrm{P}$ was determined colorimetrically while $\mathrm{Na}$ and $\mathrm{K}$ were analyzed using a flame photometer and $\mathrm{Ca}, \mathrm{Mg}, \mathrm{Fe}, \mathrm{Mn}$, and $\mathrm{Zn}$ using an atomic absorption spectrophotometer [24]. $\mathrm{Cl}$ was determined volumetrically using $0.05 \mathrm{~N}$ silver nitrate $\mathrm{AgNO}_{3}$ [25].

The soil samples were air-dried, crushed, sieved through a $2 \mathrm{~mm}$ mesh and analyzed for the following parameters: (a) $\mathrm{pH}$ was measured in a suspension with a 1:1 ratio of soil to distilled water with a pH meter [26], (b) electrical conductivity (EC) and soluble salts $\mathrm{Ca}, \mathrm{Mg}, \mathrm{K}, \mathrm{Na}$, were determined in the soil paste extract [27], (c) particle size distribution was determined using a hydrometer [28], 
(d) calcium carbonate $\left(\mathrm{CaCO}_{3}\right)$ was measured using a Bernard calcimeter [29], (e) soil organic matter (SOM) was determined by the Walkley-Black wet digestion [30], (f) cation exchange capacity was determined with the sodium acetate $\mathrm{CH}_{3} \mathrm{COONa} 1 \mathrm{~N}$ extraction method, using a flame photometer [31], (g) exchangeable cations $\mathrm{K}, \mathrm{Na}, \mathrm{Ca}, \mathrm{Mg}$ were extracted by ammonium acetate $\mathrm{CH}_{3} \mathrm{COONH}_{4} 1 \mathrm{M}, \mathrm{pH}$ $=7$. $\mathrm{Na}$ and $\mathrm{K}$ were analyzed using a flame photometer and $\mathrm{Ca}, \mathrm{Mg}$ using an atomic absorption spectrophotometer [32]. All results of exchangeable cations were calculated as the difference between exchangeable and soluble cations of soil, according to So et al. [33] (Table 3), (h) available P was determined using the $0.5 \mathrm{~N} \mathrm{NaHCO}_{3}$ extraction method [34], (i) $\mathrm{NO}_{3}-\mathrm{N}, \mathrm{NH}_{4}-\mathrm{N}$ were extracted by 2M potassium chloride $\mathrm{KCl}$ [35], (j) diethylenetriaminepentaacetic acid triethanolamine DTPA-TEA extractable $\mathrm{Fe}, \mathrm{Mn}, \mathrm{Zn}, \mathrm{Cu}$ were measured using an atomic absorption spectrophotometer [36], (k) soluble $\mathrm{Cl}$ was determined volumetrically using $0.05 \mathrm{~N}$ silver nitrate $\mathrm{AgNO}_{3}$ [32].

Table 3. Average values of soluble cations (saturated paste extract) in soil treatments.

\begin{tabular}{|c|c|c|c|c|}
\hline Treatment & $\begin{array}{c}\text { Soluble K } \\
\left(\text { meq }^{-1}\right)\end{array}$ & $\begin{array}{c}\text { Soluble Na } \\
\left(\text { meq }^{-1}\right)\end{array}$ & $\begin{array}{c}\text { Soluble Ca } \\
\left(\text { meq }^{1-1}\right)\end{array}$ & $\begin{array}{c}\text { Soluble Mg } \\
\left(\text { meq }^{-1}\right)\end{array}$ \\
\hline Act $A$ & $12.8 \pm 0.8$ & $109.7 \pm 7.9$ & $17.2 \pm 3.8$ & $34.3 \pm 14.3$ \\
\hline ActB & $13.9 \pm 1.2$ & $106.8 \pm 8.5$ & $23.0 \pm 4.5$ & $20.8 \pm 2.9$ \\
\hline Control & $11.4 \pm 1.3$ & $95.1 \pm 9.9$ & $18.7 \pm 4.0$ & $28.7 \pm 9.6$ \\
\hline CorA & $11.9 \pm 0.7$ & $92.3 \pm 5.7$ & $12.4 \pm 3.0$ & $23.5 \pm 5.0$ \\
\hline CorB & $13.0 \pm 0.9$ & $93.2 \pm 5.5$ & $20.1 \pm 4.3$ & $32.4 \pm 5.6$ \\
\hline CorC & $15.5 \pm 1.3$ & $96.8 \pm 8.9$ & $24.8 \pm 4.6$ & $21.3 \pm 1.6$ \\
\hline
\end{tabular}

\subsection{Statistical Analysis}

One-way ANOVA statistical analysis of the results was performed using the Statgraphics software application. Significant differences between treatments were determined using Tukey's HSD test with a significance level of $p \leq 0.05$.

\section{Results}

\subsection{The Effect of Biostimulant and Soil Amendment on Soil Chemical Properties}

Soil $\mathrm{pH}$ values were slightly increased by the application of ActA and ActB and by the lower organic amendment additions (CorA, CorB) but showed a significant decrease in CorC amended pots (Figure 1A). Results of one-way ANOVA showed that electrical conductivity was significantly decreased by both Actiwave treatments, with ActA being the more effective while were not significantly affected by Corresal Plus additions (Figure 1B). Soil organic matter (SOM) content was significantly higher in ActB amended pots, but was significantly lower after ActA treatment compared to control. CorB and CorC treatments did not have any significant effect on SOM content while the CorA treatment increased it (Figure 1C).

The application of both Actiwave and Corresal Plus significantly influenced available P. According to Figure 2A, the effect of Corresal plus was more drastic on the decrease of P. No significant differences were observed in the $\mathrm{NO}_{3}-\mathrm{N}$ between Actiwave treated soils and control soils (Figure 2B). Compared to control, soil $\mathrm{NO}_{3}-\mathrm{N}$ concentration was significantly higher after Corresal plus treatment. Especially CorC application resulted in significantly higher soil $\mathrm{NO}_{3}-\mathrm{N}$ concentration compared to the other two (CorA, CorB) treatments (Figure 2B). Furthermore, the amounts of soil $\mathrm{NH}_{4}-\mathrm{N}$ significantly decreased after both Actiwave and Corresal Plus treatments (Figure 2C). 

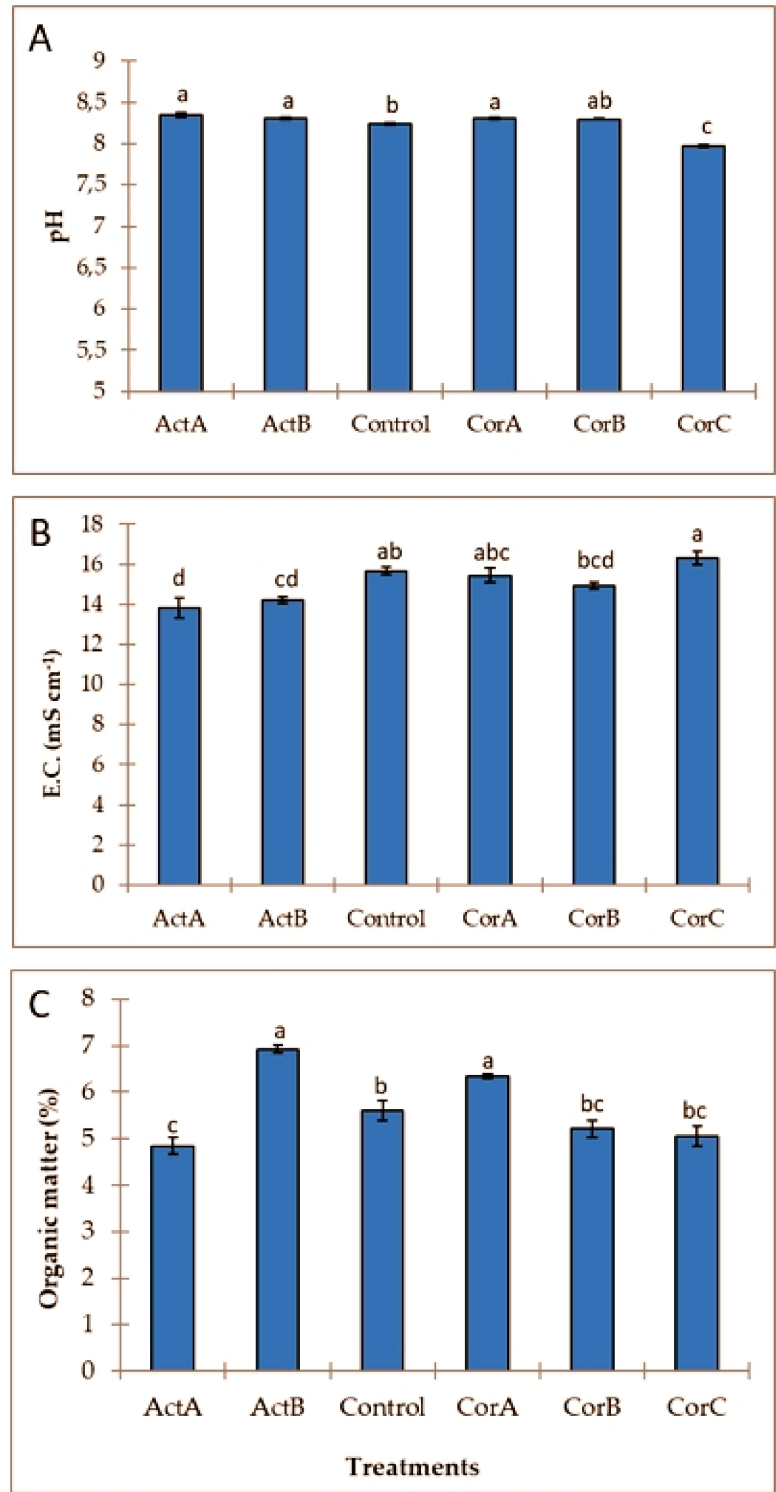

Figure 1. The effect of Actiwave (ActA, ActB) and Corresal plus (CorA, CorB, CorC) treatments on soil properties. (A) $\mathrm{pH},(\mathbf{B})$ electrical conductivity (E.C.), (C) organic matter. Bars with the same letter are not significantly different according to Tukey's test $(p \leq 0.05)$.

Soils that received a higher dose of organic amendment (CorC) presented lower exchangeable $\mathrm{K}$ values than did control and the other treated soils (Figure 3A). Soils treated with Actiwave showed significantly lower exchangeable Na concentration with ActA being more effective (Figure 3B). In the case of Corresal Plus exchangeable Na decreased in the following order: CorA $<$ CorB $<$ CorC. Exchangeable $\mathrm{Ca}$ and $\mathrm{Mg}$ levels were not significantly altered by both product treatments compared to the control soil (Figure 3C,D). Actiwave and Corresal plus application did not impact soil Mn, Fe, Zn concentration compared to control (Figure $4 \mathrm{~A}-\mathrm{C}$ ). The soluble $\mathrm{Cl}$ concentration in the soils treated with ActA was significantly lower than resulted in control soils (Figure 4D). 

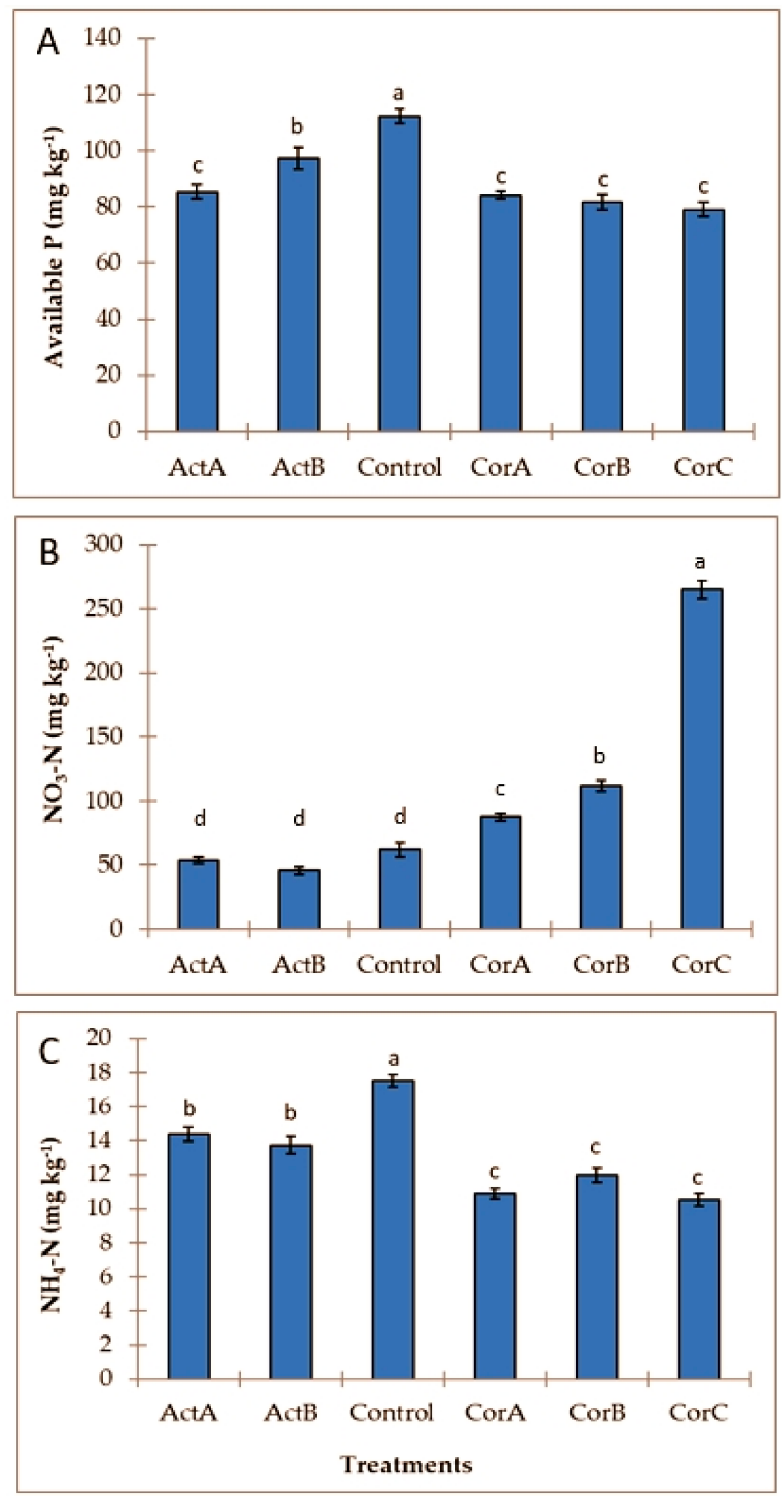

Figure 2. The effect of Actiwave (ActA, ActB) and Corresal plus (CorA, CorB, CorC) treatments on (A) Available $\mathrm{P},(\mathbf{B}) \mathrm{NO}_{3}-\mathrm{N},(\mathbf{C}) \mathrm{NH}_{4}-\mathrm{N}$. Bars with the same letter are not significantly different according to Tukey's test $(p \leq 0.05)$.
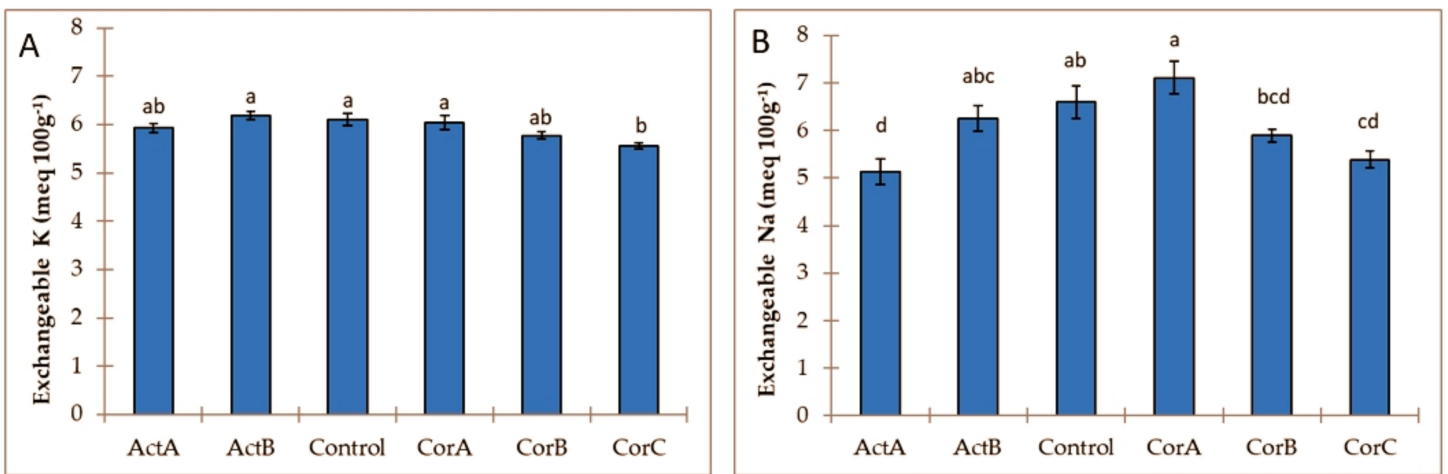

Figure 3. Cont. 

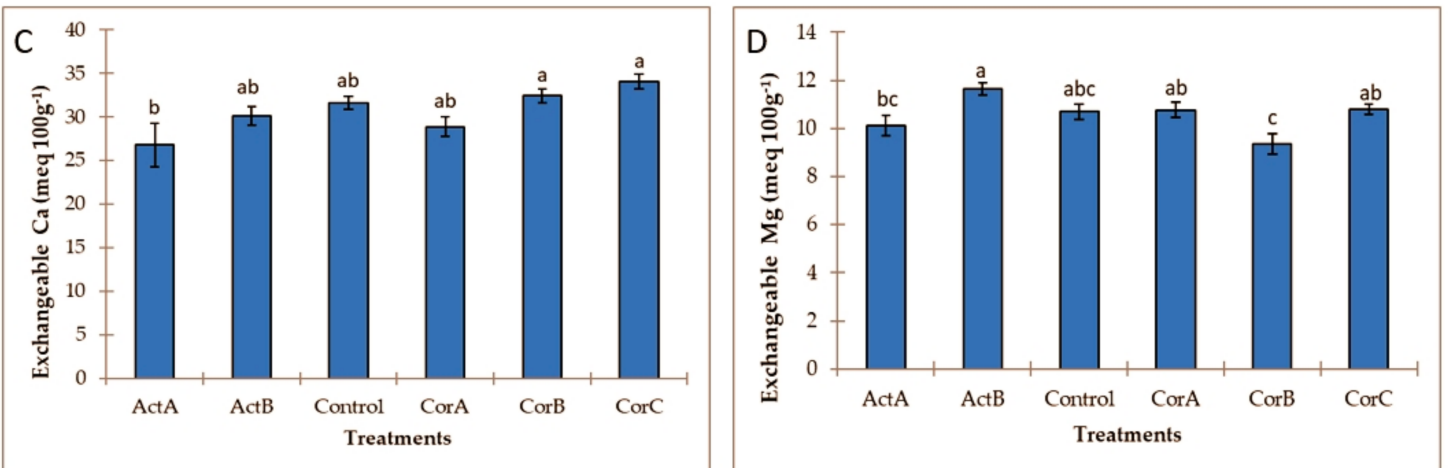

Figure 3. The effect of Actiwave (ActA, ActB) and Corresal plus treatments (CorA, CorB, CorC) on soil exchangeable cations. (A) $\mathrm{K},(\mathbf{B}) \mathrm{Na},(\mathbf{C}) \mathrm{Ca},(\mathbf{D}) \mathrm{Mg}$. Bars with the same letter are not significantly different according to Tukey's test $(p \leq 0.05)$.
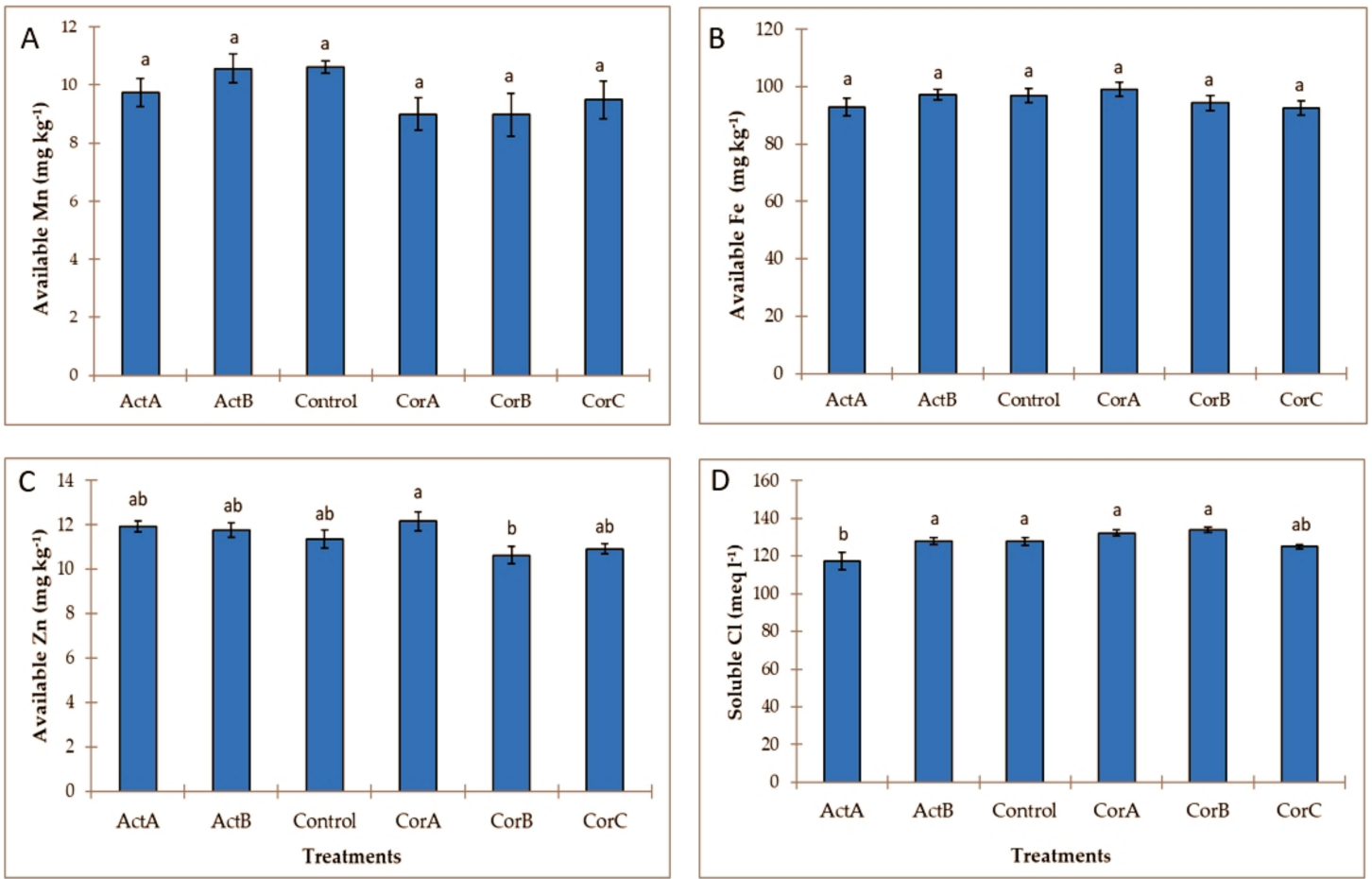

Figure 4. The effect of Actiwave (ActA, ActB) and Corresal plus (CorA, CorB, CorC) treatments on soil micronutrients. (A) $\mathrm{Mn},(\mathbf{B}) \mathrm{Fe},(\mathbf{C}) \mathrm{Zn},(\mathbf{D}) \mathrm{Cl}$. Bars with the same letter are not significantly different according to Tukey's test $(p \leq 0.05)$.

\subsection{The Effect of Biostimulant and Soil Amendment on Plant Tissues}

The results showed that lettuce biomass significantly increased after CorC treatment compared to control and the other treatments (Figure 5A). The number of lettuce leaves was similar in all treatments (Figure 5B).

Based on the results obtained on $\mathrm{N}$ leaf content, all Corresal Plus and ActB treatments appeared to increase it significantly (Figure 6A). Neither Actiwave nor Corresal Plus affected K, P, Ca and Mg leaf content. (Figure 6B-F). Treatment CorA significantly increased Na content, however, the increase is not positively correlated with the application rate (Figure 6D). 

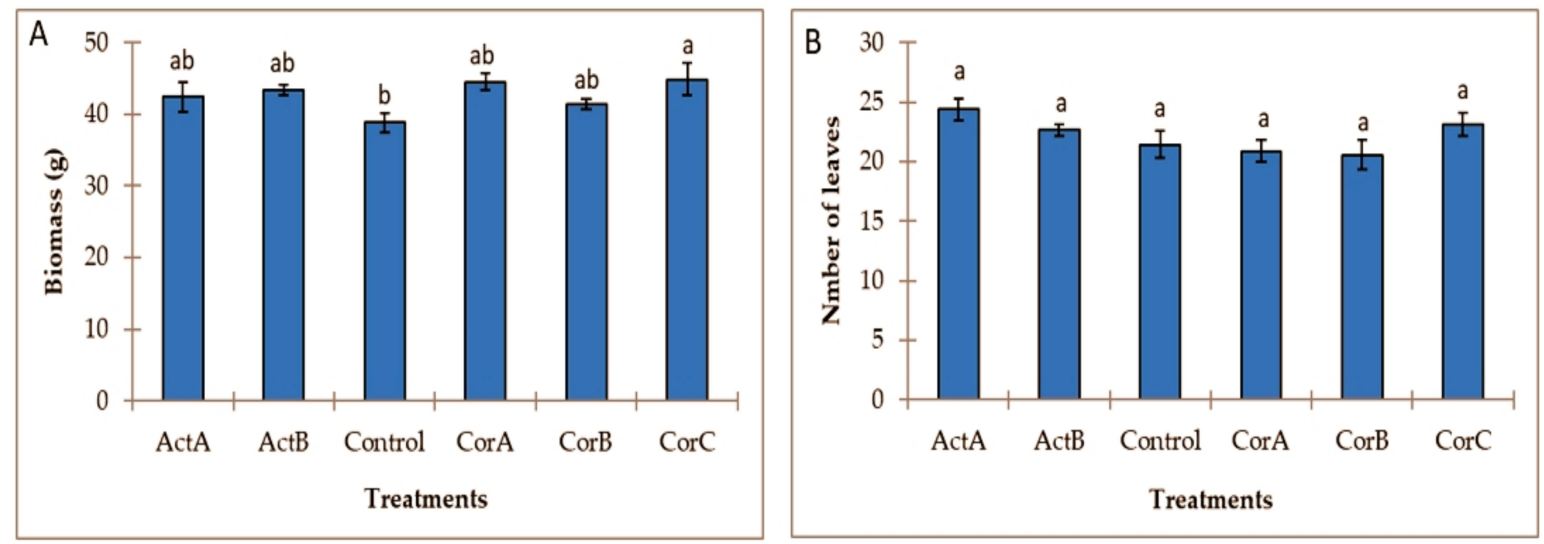

Figure 5. The effect of Actiwave (ActA, ActB) and Corresal plus (CorA, CorB, CorC) treatments on lettuce growth. (A) biomass, (B) number of leaves. Bars with the same letter are not significantly different according to Tukey's test $(p \leq 0.05)$.
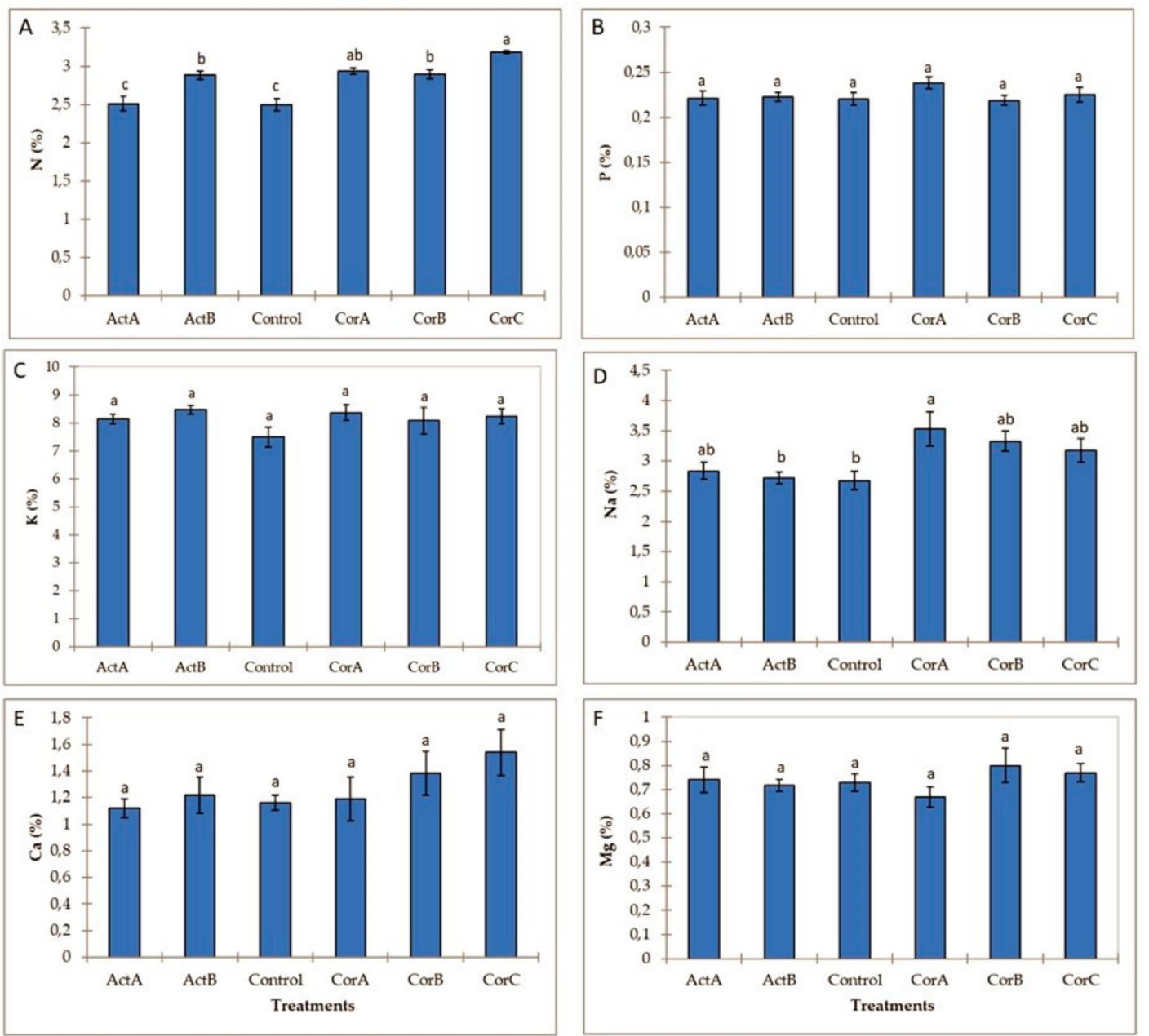

Figure 6. The effect of Actiwave (ActA, ActB) and Corresal plus (CorA, CorB, CorC) treatments on. (A) N, (B) P, (C) K, (D) Na, (E) Ca, and (F) Mg. Bars with the same letter are not significantly different according to Tukey's test $(p \leq 0.05)$.

Soils treated with Corresal plus had no significant impact on Mn, Fe, Zn concentrations, whereas ActA application significantly increased Zn concentration (Figure 7A-C). As shown in Figure 7D, leaf 
$\mathrm{Cl}$ concentration was not affected by Actiwave and CorA and CorB application but was significantly decreased by CorC application compared to control.
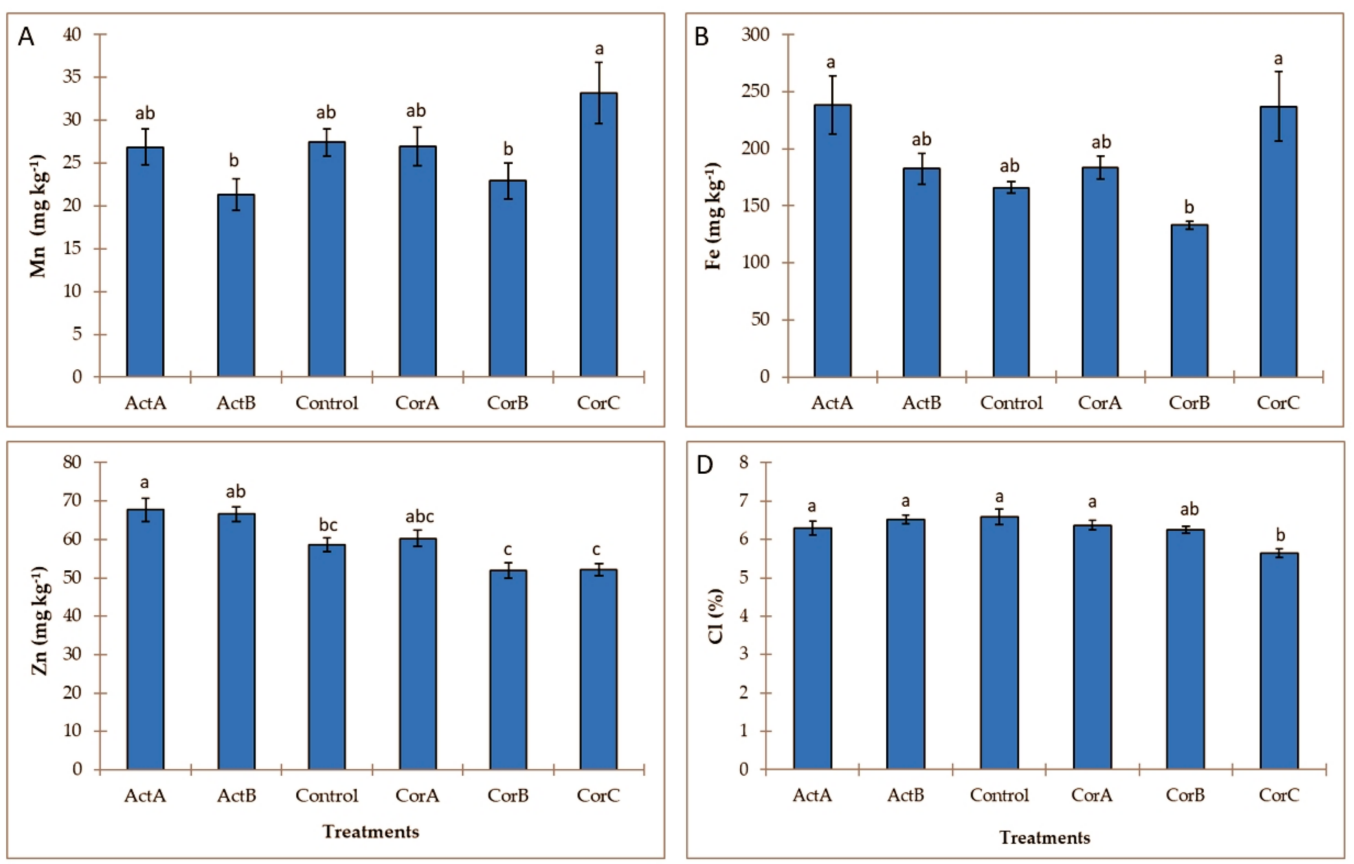

Figure 7. The effect of Actiwave (ActA, ActB) and Corresal plus (CorA, CorB, CorC) treatments on. (A) $\mathrm{Mn},(\mathbf{B}) \mathrm{Fe},(\mathbf{C}) \mathrm{Zn}$ and (D) $\mathrm{Cl}$. Bars with the same letter are not significantly different according to Tukey's test $(p \leq 0.05)$.

\section{Discussion}

The soil in all treatments has $\mathrm{pH}$ 7.9-8.4, which is characterized as moderate alkaline [37] and is higher than the optimum $\mathrm{pH}$ levels for lettuce growth ( $\mathrm{pH} \mathrm{6-7)} \mathrm{[38].} \mathrm{The} \mathrm{results} \mathrm{of} \mathrm{this} \mathrm{study}$ show that all applications of Actiwave and Corresal Plus increased $\mathrm{pH}$ except for CorC treatment, which decreased it. The soil $\mathrm{pH}$ decrease which is in agreement with the experiments conducted by Oo et al. [5] in saline and Negim [39] in calcareous saline-sodic soils, might be explained by the acidic nature of the amendments, as in the case of the Corresal Plus (Table 2) and to the acidifying effect of organic acids and $\mathrm{H}^{+}$produced from the decomposition of the amendment's organic matter content. Moreover, the higher dose of Corresal Plus (CorC) resulted in higher soil $\mathrm{NO}_{3}-\mathrm{N}$ concentration (Figure 2B) compared to control. It is well known that during nitrification, $\mathrm{H}^{+}$are produced, which decrease soil $\mathrm{pH}[40,41]$. However, in this study, soil $\mathrm{pH}$ did not show a substantial decrease with organic amendment dose. According to Mahdy's [42], the impact on soil pH is less drastic with the application of soil amendments enriched in $\mathrm{CaCO}_{3}$. Therefore, in this study, it is likely that the $\mathrm{CaCO}_{3}$ content of the saline-sodic soil buffer Corresal Plus acidity resulting in non-drastic changes of soil pH.

According to Figure 1B, E.C. decreased in all Actiwave treatments. In experiments by Spinelli et al. [21], the application of Actiwave resulted in stimulation of root growth, which consequently improved nutrient uptake by roots. Similar results were reported by Çimrin et al. [43] who found that humic acid applications increased root weight and length and as a result nutrient uptake by roots was enhanced. Corresal plus application did not have any significant effect on electrical conductivity. A similar case has been reported by Walker and Bernal [44] where olive mill waste compost and poultry manure were added as organic amendments to a saline soil cultivated with sea beet and sugar beet.

The SOM content is above the critical threshold of $3.4 \%$ for all treatments $[45,46]$. Although in most cases, amendment application had a positive effect on SOM levels [5,47], our results indicate that the initial high SOM content (control soil) (Table 1) probably masks the positive effects of the two products on SOM. 
Soil available P in all treatments is characterized as excessive [37]. However, soil treated with Corresal Plus resulted in significantly lower available P compared to control. Corresal Plus contains significant amounts of $\mathrm{Ca}$ (Table 2) which bind $\mathrm{P}$ to insoluble forms and therefore $\mathrm{P}$ precipitate as calcium phosphates reducing its availability $[1,9,10]$. Studies show that the addition of amendments rich in Ca like gypsum in calcareous saline-sodic soils also reduced available P because Ca that was released from gypsum's dissolution forms insoluble compounds with phosphates [48]. Leaf P content is $0.2 \%$ and is below the optimum level $(0.45-0.80 \%)$ for lettuce, according to Mills and Benton [39]. All treatments did not significantly change leaf $\mathrm{P}$ content in agreement with Rady [49]. According to Shannon and Grieve [14], lettuce cultivation under saline conditions increased $\mathrm{Na}$ and $\mathrm{Cl}$ ions in plant tissues and decreased $\mathrm{Ca}, \mathrm{K}$, and $\mathrm{PO}_{4}$ ions. Similarly, Roussos et al. [50] reported that in high salinity conditions, there is a significant decrease of $\mathrm{P}$ content of jojoba explants.

In the soils treated with Corresal Plus, $\mathrm{NO}_{3}-\mathrm{N}$ increased in all treatments, and the higher concentrations were observed in CorC treatment. The significant increase of soil $\mathrm{NO}_{3}-\mathrm{N}$ in CorC is attributed to the high $\mathrm{N}$ content of Corresal Plus at this dose (Table 2). This is in agreement with the pronounced response of lettuce to $\mathrm{N}$ fertilization which was observed for the soils treated with CorC along with the highest biomass weight (Figures $5 \mathrm{~A}$ and $6 \mathrm{~A}$ ). In contrast, $\mathrm{NH}_{4}-\mathrm{N}$ decreased in all treatments probably due to the uptake of plants, nitrification process and the adsorption from clay minerals and organic matter (Figure 2C). Leaf $\mathrm{N}$ content ranges from 2.5 to $3.2 \%$ and is close to $3.5 \%$, the lower optimum level, according to Mills and Benton [41]. These results showed that the incorporation of both products, which have significant amounts of $\mathrm{N}$, increased the $\mathrm{N}$ content of lettuce leaves compared with that of the control plants. Similar results have been previously reported by Lucini et al. [51].

Soil exchangeable $\mathrm{K}$ is characterized as excessive [37]. Oo et al. [5] found that the application of organic amendments rich in $\mathrm{K}$ (compost and vermicompost) had a positive impact on soil exchangeable $\mathrm{K}$. Leaf $\mathrm{K}$ content ranges from 7.8 to $8.4 \%$ and is above the optimum levels (5.5-6.2\%), according to Mills and Benton [41]. Lucini et al. [51] reported similar results when a saline soil was ameliorated with soil and foliar application of biostimulant products. According to Cha-um et al. [52], the incorporation of organic amendments increased the leaf $\mathrm{K}$ content of Jasmine rice.

High exchangeable Na concentrations were observed, almost 30-fold above the normal values in most soils $\left(0.2\right.$ meq $\left.100 \mathrm{~g}^{-1}\right)$. The treatments of ActA and CorC resulted in significantly lower exchangeable Na compared to control (Figure 3B) suggesting that the effects of biostimulant and organic amendment on $\mathrm{Na}$ content in the saline-sodic soil are in agreement with the applied doses and the composition of the applied products. Corresal plus contains significant amounts of $\mathrm{Ca}$ (Table 2). The higher the dose, the higher the increase of $\mathrm{Ca}$ that can replace $\mathrm{Na}$ from soil exchange sites decreasing soil sodicity. Similarly, Walker and Bernal [44] reported that the application of organic amendments with high Ca content resulted in significantly higher soil exchangeable Ca concentration compared to control. Organic amendment and biostimulant application did not induce significant changes in leaf $\mathrm{Na}$ content, except for CorA treatment which increased it. Leaf Ca content ranges from 1.2 to $1.5 \%$ and is below optimum levels (2.0-2.8\%), according to Mills and Benton [41]. A trend was observed for higher leaf Ca content with increased rates of Corresal Plus application. Soil exchangeable Mg concentrations are high due to the effect of soil parent material which is rich in ferromagnesian minerals [22]. Leaf magnesium content ranges from 0.7 to $0.8 \%$ and is at optimum levels $(0.6-0.8 \%)$, according to Mills and Benton [41].

Soil available Mn concentrations are at sufficient levels [36,53]. Leaf Mn content ranges from 21 to $27 \mathrm{mg} \mathrm{kg}^{-1}$ and is close to the lowest optimum levels (11-250 mg kg-1), according to Mills and Benton [41]. Due to the origin of the studied soil, available Fe is very high and therefore no significant effects have been observed in the treatments compared to control. Leaf Fe content ranges from 133 to $238 \mathrm{mg} \mathrm{kg}^{-1}$ and is above optimum levels (40-100 mg kg-1) according to Mills and Benton [41]. Moreover, leaf $\mathrm{Zn}$ content ranges from 51 to $67 \mathrm{mg} \mathrm{kg}^{-1}$ and falls in the optimum levels (20-250 $\mathrm{mg} \mathrm{kg}^{-1}$ ) [41]. Actiwave contains Zn-EDTA and the low dose of Actiwave significantly 
increased Zn content. In addition, Act A significantly decreased soil $\mathrm{Cl}$ concentrations, while $\mathrm{Cl}$ content in lettuce leaves decreased when Corresal Plus was added to the higher dose (CorC).

Based on the results of this study, Actiwave, as a biostimulant product, boosts the uptake of nutrients and enhances lettuce plants to overcome salinity and sodicity stress by decreasing soil E.C., soil exchangeable $\mathrm{Na}$, soluble $\mathrm{Cl}$ and increasing leaf $\mathrm{N}$ and $\mathrm{Zn}$ content. On the other hand, Corresal Plus (organic amendment) treatments decrease soil $\mathrm{pH}$, soil exchangeable $\mathrm{Na}$, leaf $\mathrm{Cl}$ content and increase soil $\mathrm{NO}_{3}-\mathrm{N}$, leaf $\mathrm{N}$ content and lettuce biomass. However, Corresal plus application did not seem to have any significant effect on soil E.C.

In the present study, the high SOM content and the calcareous nature of saline-sodic soil were likely to play a major role in reducing the negative effects of salinity-sodicity on nutrient status of lettuce plants masking in most cases the beneficial effects of the Actiwave and Corresal Plus products. Previous researchers have suggested that the efficacy of organic amendments is strongly reduced when applied in soils with high levels of SOM. According to Kelting et al., Hartzs and Bottoms, and Leventoglu and Erdal [54-56], high levels of endogenous SOM would likely negate any positive effects of organic amendments (humic substances) when applied to soils.

\section{Conclusions}

In this experiment, two commercial products were tested for their efficacy in addressing the negative effects of salinity-sodicity on the soil properties and the nutrient status of lettuce plants. The two products, Actiwave (biostimulant) and Corresal Plus (organic amendment) showed beneficial effects on soil properties like E.C., $\mathrm{pH}$ and on soil nutrients like $\mathrm{NO}_{3}-\mathrm{N}$. Furthermore, the application of both products significantly reduced soil exchangeable Na. Leaves' nutrient content under all treatments was less affected, except for $\mathrm{N}$ and $\mathrm{Zn}$ that were significantly enhanced. Nonetheless, in most cases, the products tested did not provoke significant changes indicating that their positive effects were probably masked by the high SOM content and the calcareous nature of the studied soil. In terms of sustainable management of soil nutrients, further research is needed in order to elucidate the role of biostimulants and organic amendments application in calcareous saline-sodic soil with high SOM content.

Author Contributions: S.K. performed pot experiment, analysis data, interpret the results and wrote the manuscript. D.G. supervised this research, suggested the data analysis, reviewed the manuscript and gave valuable comments.

Funding: This research received no external funding.

Acknowledgments: We would like to thank Agrifert S.A. and Valagro Hellas S.A. for providing the products tested.

Conflicts of Interest: The authors declare no conflict of interest.

\section{References}

1. Shrivastava, P.; Kumar, R. Soil salinity: A serious environmental issue and plant growth promoting bacteria as one of the tools for its alleviation. Saudi J. Biol. Sci. 2015, 22, 123-131. [CrossRef] [PubMed]

2. Zia-ur-Rehman, M.; Murtaza, G.; Qayyum, M.F.; Saifullah, R.M.; Ali, S.; Akmal, F.; Khalid, H. Degraded Soils: Origin, Types and Management. In Soil Science: Agricultural and Environmental Prospectives; Hakeem, K.R., Akhtar, J., Sabir, M., Eds.; Springer International Publishing: Cham, Switzerland, 2016; pp. 23-65.

3. Tejada, M.; Garcia, C.; Gonzalez, J.L.; Hernandez, M.T. Use of organic amendment as a strategy for saline soil remediation: Influence on the physical, chemical and biological properties of soil. Soil Biol. Biochem. 2006, 38, 1413-1421. [CrossRef]

4. Laudicina, V.A.; Hurtado, M.D.; Badalucco, L.; Delgado, A.; Palazzolo, E.; Panno, M. Soil chemical and biochemical properties of a salt-marsh alluvial Spanish area after longterm reclamation. Biol. Fert. Soils 2009, 45, 691-700. [CrossRef]

5. Oo, A.N.; Iwai, C.B.; Saenjan, P. Soil properties and maize growth in saline and nonsaline soils using cassava-industrial waste compost and vermicompost with or without earthworms. Land Degrad. Dev. 2015, 26, 300-310. [CrossRef]

6. Zeinolabedin, J. The Effects of Salt stress on plant growth. Tech. J. Eng. Appl. Sci. 2012, 2, 7-10. 
7. Chung, J.-B.; Jin, S.-J.; Cho, H.-J. Low Water Potential in Saline Soils Enhances Nitrate Accumulation of Lettuce. Commun. Soil Sci. Plant Anal. 2005, 36, 1773-1785. [CrossRef]

8. Hu, Y.; Burucs, Z.; Tucher, S.; Schmidhalter, U. Short-term effects of drought and salinity on mineral nutrient distribution along growing leaves of maize seedlings. Environ. Exp. Bot. 2007, 60, 268-275. [CrossRef]

9. Fageria, N.K.; Gheyi, H.R.; Moreira, A. Nutrient Bioavailability in salt affected soils. J. Plant Nutr. 2011, 34, 945-962. [CrossRef]

10. Niste, M.; Vidican, R.; Rotar, I.; Stoian, V.; Pop, R.; Miclea, R. Plant Nutrition Affected by Soil Salinity and Response of Rhizobium Regarding the Nutrients Accumulation. ProEnvironment 2014, 7, 71-75.

11. Machado, R.M.A.; Serralheiro, R.P. Soil Salinity: Effect on Vegetable Crop Growth. Management Practices to Prevent and Mitigate Soil Salinization. Horticulturae 2017, 3, 30. [CrossRef]

12. Hernandez, T.; Chocano, C.; Moreno, H.L.; Garcia, C. Use of compost as an alternative to conventional inorganic fertilizers in intensive lettuce (Lactuca sativa L.) crops-effect on soil and plant. Soil Tillage Res. 2016, 160, 14-22. [CrossRef]

13. Havlin, J.L.; Tisdale, S.L.; Nelson, W.L.; Beaton, J.D. Soil acidity and alkalinity. In Soil Fertility and Fertilizers: An Introduction to Nutrient Management, 7th ed.; Pearson: Upper Saddle River, NJ, USA, 2005; pp. 98-114.

14. Shannon, M.C.; Grieve, C.M. Tolerance of vegetable crops to salinity. Sci. Hortic. 1999, 78, 5-38. [CrossRef]

15. Wu, W.; Ma, B. Integrated nutrient management (INM) for sustaining crop productivity and reducing environmental impact: A review. Sci. Total Environ. 2015, 512, 415-427. [CrossRef] [PubMed]

16. Wallace, A.; Terry, E.R. Handbook of Soil Conditioners, Substances that Enhance the Physical Properties of Soil; Dekker, M., Ed.; CRC Press: New York, NY, USA, 1998.

17. Abbott, L.K.; Macdonald, L.M.; Wong, M.T.F.; Webb, M.J.; Jenkins, S.N.; Farrell, M. Potential roles of biological amendments for profitable grain production-A review. Agric. Ecosyst. Environ. 2018, 256, 34-50. [CrossRef]

18. Halpern, M.; Bar-Tal, A.; Ofek, M.; Minz, D.; Muller, T.; Yermiyahu, U. The Use of Biostimulants for Enhancing Nutrient Uptake. Adv. Agron. 2015, 130, 141-174. [CrossRef]

19. Bulgari, R.; Cocetta, G.; Trivellini, A.; Vernieri, P.; Ferrante, A. Biostimulants and crop responses: A review. Biol. Agric. Hortic. 2015, 31, 1-17. [CrossRef]

20. Vernieri, P.; Borghesi, E.; Ferrante, A.; Magnani, G. Application of biostimulants in floating system for improving rocket quality. J. Food Agric. Environ. 2005, 3, 86-88.

21. Spinelli, F.; Fiori, G.; Noferini, M.; Sprocatti, M.; Costa, G. Perspectives on the use of a seaweed extract to moderate the negative effects of alternate bearing in apple trees. J. Hortic. Sci. Biotechnol. 2009, 84, 131-137. [CrossRef]

22. Vouzoulidou-Alexandrou, E.G.; Polyzopoulos, N.A.; Mourizaki-Karanikolaou, E.G.; Panagiotopoulos, K.P. Study of Soil Fertility of the Farm of Aristotle University Thessaloniki; Scientific Yearbook of Faculty of Agriculture and Forestry: Thessaloniki, Greece, 1977; Volume, K.

23. Bremmer, J.M.; Mulvaney, C.S. Nitrogen—total, principles of Kjeldahl methods. In Methods of Soil Analysis Chemical and Mineralogical Properties, 2nd ed.; (part 2); Page, A.L., Miller, R.H., Keeney, D.R., Eds.; Agronomy: Madison, WI, USA, 1982; Volume 9, pp. 599-616.

24. Westerman, L.R. Soil Testing and Plant Analysis, 3th ed.; Soil Science Society of America: Madison, WI, USA, 1990.

25. Edwards, I.K.; Kalra, Y.P.; Radford, F.G. Chloride determination and levels in the soil-plant environment. Environ. Pollut. 1981, 2, 109-117. [CrossRef]

26. Thomas, G.W. Soil pH and Soil Acidity. In Methods of Soil Analysis, Part 3. Chemical Methods; Sparks, D.L., Page, A.L., Helmke, P.A., Loeppert, R.H., Soltanpour, P.N., Tabatabai, M.A., Johnston, C.T., Summer, M.E., Eds.; Published Soil Science of America, Inc.: Madison, WI, USA, 1996.

27. Corwin, D.L.; Lesch, S.M.; Shouse, P.J.; Soppe, R.; Ayars, J.E. Identifying soil properties that influence cotton yield using soil sampling directed by apparent soil electrical conductivity. Agron. J. 2003, 95, 352-364. [CrossRef]

28. Bouyoucos, G.H. A recalibration of the hydrometer method for making mechanical analysis of soils. Agron. J. 1951, 43, 434-438. [CrossRef]

29. Horton, S.H.; Newsom, D.W. A rapid gas evaluation method for calcium carbonate equivalent in liming materials. Soil Sci. Soc. Am. 1953, 17, 414-415. [CrossRef]

30. Nelson, D.W.; Sommers, L.E. Total Carbon, Organic Carbon and Organic Matter. In Methods of Soil Analysis, Part 3. Chemical Methods; Sparks, D.L., Page, A.L., Helmke, P.A., Loeppert, R.H., Soltanpour, P.N., 
Tabatabai, M.A., Johnston, C.T., Summer, M.E., Eds.; Published Soil Science of America, Inc.: Madison, WI, USA, 1996; Chapter 34; pp. 961-1002.

31. Rhoades, J.D. Cation exchange capacity. In Methods of Soil Analysis. Part 2. Chemical and Microbiological Properties, 2nd ed.; Page, A.L., Miller, R.H., Keeney, D.R., Eds.; Soil Science Society of America: Madison, WI, USA, 1982; Chapter 8; pp. 149-174.

32. Thomas, G.W. Exchangeable cations. In Methods of Soil Analysis. Part 2 Chemical and Microbiological Properties, 2th ed.; Page, A.L., Miller, R.H., Keeney, D.R., Eds.; Soil Science Society of America: Madison, WI, USA, 1982.

33. So, H.B.; Menzies, N.W.; Bigwood, R.; Kopittke, P.M. Examination into the Accuracy of Exchangeable Cation Measurement in Saline Soils. Commun. Soil Sci. Plant Anal. 2006, 37, 1819-1832. [CrossRef]

34. Olsen, S.R.; Sommer, L.E. Phosphorus. In Methods of Soil Analysis; Page, A.L., Miller, R.H., Keeney, D.R., Eds.; Soil Science Society of America: Madison, WI, USA, 1982; pp. 403-430.

35. Mulvaney, R.L. Nitrogen-Inorganic Forms. In Methods of Soil Analysis, Part 3. Chemical Methods; Sparks, D.L., Page, A.L., Helmke, P.A., Loeppert, R.H., Soltanpour, P.N., Tabatabai, M.A., Johnston, C.T., Summer, M.E., Eds.; Published Soil Science of America, Inc.: Madison, WI, USA, 1996; Chapter 38; pp. 1123-1155.

36. Lindsay, W.L.; Norvell, W.A. Development of a DTPA soil test for zinc, iron, manganese and copper. Soil Sci. Soc. Am. J. 1978, 42, 421-428. [CrossRef]

37. Horneck, D.A.; Sullivan, D.M.; Owen, J.S.; Hart, J.M. Soil Test Interpretation Guide. In Oregon State University Extension Publication EC 1478; Oregon State University: Corvallis, OR, USA, 2011.

38. Penas, E.J.; Lindgren, D.T. G90-945 A Gardener's Guide for Soil and Nutrient Management in Growing Vegetables; Historical Materials from University of Nebraska-Lincoln Extension: Lincoln, OR, USA, 1990; p. 1017.

39. Negim, O. Effect of Addition Pressmud and Gypsum by Product to Reclamation of Highly Calcareous Saline Sodic Soil. Am. Assoc. Sci. Technol. J. Environ. I. 2015, 1, 76-84.

40. Brady, N.C.; Weil, R.R. Soils of dry regions: Alkalinity, salinity and sodicity. In The Nature and Properties of Soils, 14th ed.; Pearson Editions: New Jersey, NJ, USA, 2008; Chapter 10; pp. 411-441.

41. Mills, A.H.; Benton, A.J.; Jones, J.B., Jr. Plant Analysis Handbook II: A Practical Sampling, Preparation, Analysis and Interpretation Guide; MicroMacro Publising, Inc.: Athens, GA, USA, 1996; pp. 364-365.

42. Mahdy, A.M. Comparative Effects of Different Soil Amendments on Amelioration of Saline-Sodic Soils. Soil Water Res. 2011, 6, 205-216. [CrossRef]

43. Çimrin, M.K.; Türkmen, O.; Turan, M.; Tuncer, B. Phosphorus and humic acid application alleviate salinity stress of pepper seedling. Afr. J. Biotechnol. 2010, 9, 5845-5851.

44. Walker, J.D.; Bernal, M.P. The effects of olive mill waste compost and poultry manure on the availability and plant uptake of nutrients in a highly saline soil. Bioresour. Technol. 2008, 99, 396-403. [CrossRef]

45. Loveland, P.; Webb, J. Is there a critical level of organic matter in the agricultural soils of temperate regions: A review. Soil Tillage Res. 2003, 70,1-18. [CrossRef]

46. Musinguzi, P.; Tenywa, J.S.; Ebanyat, P.; Tenywa, M.M.; Mubiru, D.N.; Basamba, T.A.; Leip, A. Soil Organic Carbon Thresholds and Nitrogen Management in Tropical Agroecosystems: Concepts and Prospects. J. Sustain. Dev. 2013, 6, 12. [CrossRef]

47. Wang, L.; Sun, X.; Li, S.; Zhang, T.; Zhang, W.; Zhai, P. Application of Organic Amendments to a Coastal Saline Soil in North China: Effects on Soil Physical and Chemical Properties and Tree Growth. PLoS ONE 2014, 9, e89185. [CrossRef] [PubMed]

48. Yazdanpanah, N.; Ebrahim, P.; Ali, N.; Mahmoodabadi, M.; Sinobas, L.R. Erclamation of calcareous saline sodic soil with different amendments (II): Impact on nitrogen, phosphorus and potassium redistribution and on microbial respiration. Agric. Water Manag. 2013, 120, 39-45. [CrossRef]

49. Rady, M.M. A novel organo-mineral fertilizer can mitigate salinity stress effects for tomato production on reclaimed saline soil. S. Afr. J. Bot. 2012, 81, 8-14. [CrossRef]

50. Roussos, P.A.; Gasparatos, D.; Tsantili, E.; Pontikis, C.A. Mineral nutrition of jojoba explants in vitro under sodium chloride salinity. Sci. Hortic. 2007, 114, 59-66. [CrossRef]

51. Lucini, L.; Rouphael, Y.; Cardarelli, M.; Canaguier, R.; Kumar, P.; Colla, G. The effect of a plant-derived biostimulant o-n metabolic profiling and the crop performance of lettuce grown under saline conditions. Sci. Hortic. 2015, 182, 124-133. [CrossRef]

52. Cha-um, S.; Pokasombat, Y.; Kirdmane, C. Remediation of salt-affected soil by gypsum and farmyard manure - Importance for the production of Jasmine rice. Aust. J. Crop Sci. 2011, 5, 458-465. 
53. Chatzistathis, T.; Papaioannou, A.; Gasparatos, D.; Molassiotis, A. From which soil metal fractions Fe, Mn, $\mathrm{Zn}$ and $\mathrm{Cu}$ are taken up by olive trees (Olea europaea L. cv. 'Chondrolia Chalkidikis') in organic groves? J. Environ. Manag. 2017, 203, 489-499. [CrossRef]

54. Kelting, M.; Harris, J.R.; Fanelli, J.; Appleton, B. Biostimulants and soil amendments affect two-year posttransplant growth of red maple and Washington Hawthorn. HortScience 1998, 33, 819-822. [CrossRef]

55. Hartz, T.K.; Bottoms, T.G. Humic Substances Generally Ineffective in Improving Vegetable Crop Nutrient Uptake or Productivity. HortScience 2010, 45, 906-910. [CrossRef]

56. Leventoglu, H.; Erdal, I. Effect of High Humic Substance Levels on Growth and Nutrient Concentration of Corn under Calcareous Conditions. J. Plant Nutr. 2014, 37, 2074-2084. [CrossRef]

(C) 2019 by the authors. Licensee MDPI, Basel, Switzerland. This article is an open access article distributed under the terms and conditions of the Creative Commons Attribution (CC BY) license (http://creativecommons.org/licenses/by/4.0/). 